\section{What substitutes for oil?}

\section{David Spurgeon reports on a forthcoming conference on future sources of organic raw materials}

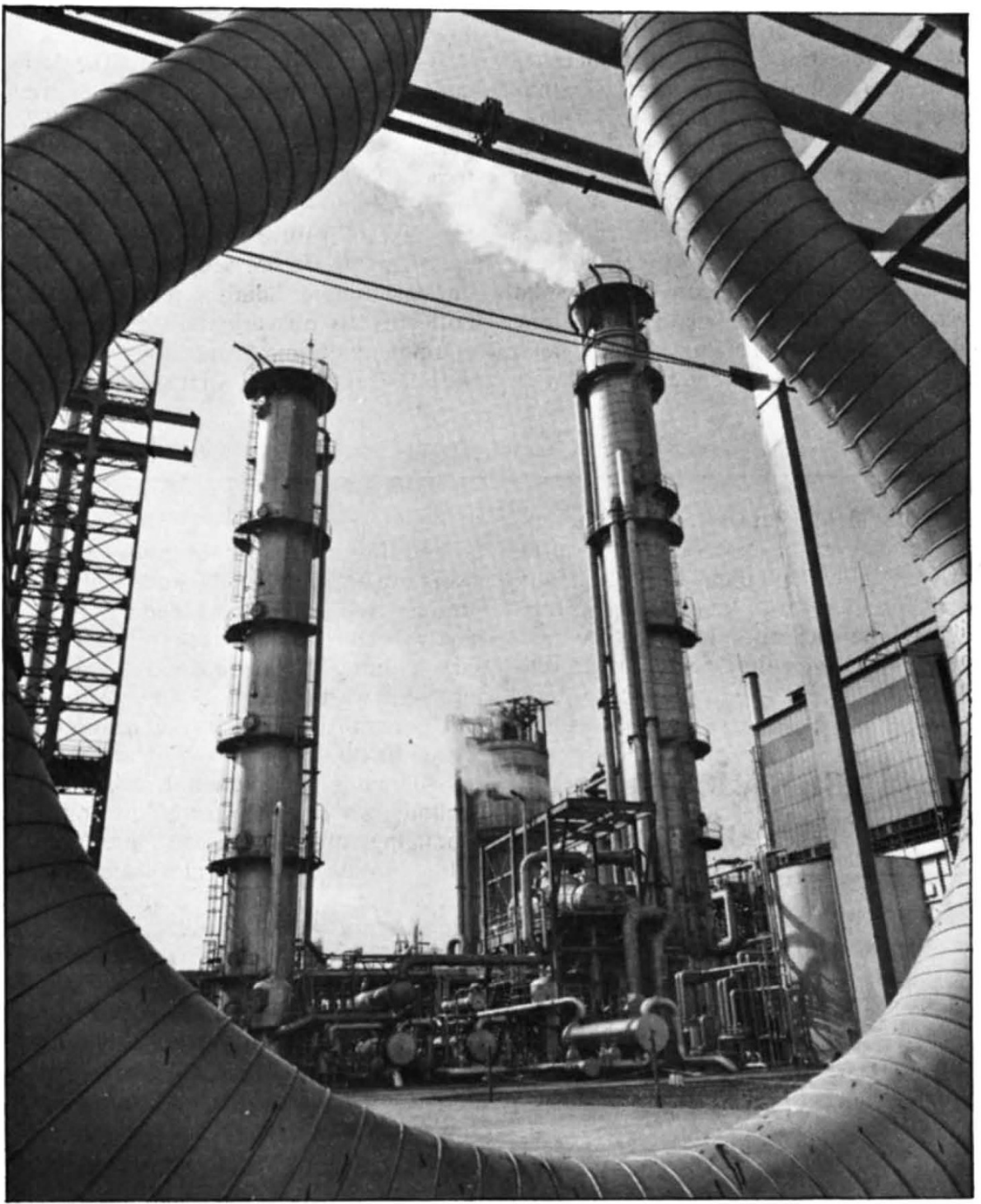

FVER since the OPEC price squeeze drew world attention to the dwindling supplies of oil some five years ago, attention has focused on replacements for petroleum as a fuel. But recently, the vast international chemical industry has begun to concern itself with the prospect of the eventual loss of petroleum as feedstock - and indeed with the entire question of the planet's diminishing supplies of natural resources.

In pursuit of this theme, the International Union of Pure and Applicd Chemistry proposed a first World Conference on Future Sources of Organic Raw Materials through its CHEMRAWN programme (Chemical Research Applied to World Needs). Cosponsored by the Chemical Institute of Canada and the American Chemical Society, the conference is to be held in Toronto, Canada, 10-13 July.
Although most experts do not see petroleum supplies disappearing for at least the next 20 years, oil will inevitably become more and more expensive as supplies diminish. Dr B. W. Rossiter, director of Eastman Kodak Research Laboratories and chairman of the CHEMRAWN committee, said recently that about seven per cent of refined petroleum currently is diverted for chemical use. "Even if petroleum were reserved for chemical use, costs would still rise dramatically. Other sources of carbon-based materials could then become economically more competitive. Consequently it is vital whatever happens - to learn how to derive useful feedstocks and chemicals from such items as coal. It will also be necessary to perfect recycling methods and to develop entirely renewable resources for forestation, crops, or other parts of the biomass."
The first big push: coal

The general chairman of the conference, Dr W. G. Schneider, president of the National Research Council of Canada, says that the problem is much broader than feedstocks.

"We want to identify alternative resources from a long-term perspective, and identify and share those technologies that are going to be needed to exploit them, particularly small-scale technologies. We're really slanting this whole thing at the turn of the century. What organic raw materials are we going to need at the turn of the century and beyond? We're looking at everything the chemical industry produces - plastics, pharmaceuticals, solvents, agricultural chemicals. A large part of our clothing, food and health require a large amount of chemical processing. We want to examine what the possibilities and the options are."

Some of the options to be considered, besides coal, are wood, plants of various kinds from both land and sea, forest and crop residues, animal and human wastes, liquid fuels such as methanol and ethanol, genetic engineering of microorganisms, anaerobic microbial digestion combined with photosynthesis, and synthetic organic photochemistry.

The first big push for oil substitutes will probably be in the direction of coal. US President Jimmy Carter recognised its importance last year by proposing an increase in the mining and use of coal to 1.2 billion tons annually by 1985 - a proposal that met with broad support from both Congress and the public.

The United States Department of Energy is sponsoring projects in both gasification and liquefaction of coal, and will at the same time explore possibilities of production of chemicals such as ammonia. carbon monoxide, hydrogen and aromatics. Germany also has a government-sponsored programme to produce chemicals from coal.

Germany in fact was the site of development of the first coal liquefaction processes in the $1920 \mathrm{~s}$ and $30 \mathrm{~s}$, and these processes were used on a commercial scale in the second world war. None of them are economic today, however, and the outlook for liquefaction plants that are economically competitive with petroleum as chemical feedstocks is not considered good until the 1990s.

Fortunately, world supplies of coal appear sufficient to meet the need for both fuels and chemical feedstocks for some decades at least. According to a report by Paul Averitt (US Geological Survey Report, 1969, "Coal Resources of the United States", US Geological Survey Bulletin 1275) the world's initial recoverable coal supply ranges between 
about two and eight trillion $\left(10^{12}\right)$ tonnes, depending on the depths and thickness of the seams. Of this, $161 \times$ $10^{\circ}$ tonnes-or between two and eight per cent - had already been consumed. M. King Hubbert, formerly of the United States Geological Survey, estimates that the peak in the rate of world coal production will probably occur between the years 2100 and 2200.

\section{Brazil takes the lead}

One of the most interesting experiments in energy-source substitution is taking place in Brazil, and it may point the way for other countries. Prompted by a massive increase in petroleum imports, (which supplied 13.2\% of the country's energy needs in 1940 and $43.6 \%$ in 1976), the Brazilian government examined alternatives such as coal, wood, bagasse, ethyl alcohol, vegetable oils, methane and hydrogen; as well as hydro and nuclear power generation, conservation methods, and solar, wind and tidal energy.

In 1975, a National Alcohol Programme was set up to exploit ethanol both as fuel for automotive use (mixed with gasoline), and as a raw material for the chemical industry. Based on future needs, the government forecasts an increase in anhydrous alcohol consumption exclusively for automotive use of 0.73 million $\mathrm{m}^{3}$ in 1977 to 4.38 million $\mathrm{m}^{3}$ in 1986 .

The methanol is obtained mainly from sugarcane, cassava, babaçú and sugar sorghum, and the governmentsponsored programme is searching for new uses for the residues and byproducts of the process (stillage, bagasse and yeast). It is also examining problems of distribution of the alcohol.

Production of five million $\mathrm{m}^{3}$ of anhydrous alcohol is the goal by 1986 , which will require an estimated investment of about $\$ 2.65$ billion. In 1977 the Brazilian government was investing $\$ 500$ million in the programme but it estimates it will save from $\$ 3$ to $\$ 5$ billion in foreign exchange between 1977 and 1986 - no small saving for a developing country.

\section{Offshore seaweed farms}

Biomass is another promising alternative to petroleum as a source of both energy and chemical feedstocks. One form being proposed is seaweed, which could be farmed offshore and harvested. Both developed and developing countries could use such a resource to advantage.

One proposal envisages a farm of 100,000 acres growing the alga Macrocystis pyrifera 100 miles off the coast of California, which would also have kelp bass and oyster cultivation associated with it. It would produce 42.5 tons of solid material per acre per year, of which 23.8 tons would be volatile. Calculations suggest that such a farm could produce $22.1 \times 10^{9}$ cubic feet of synthetic natural gas annually at $\$ 3.65$ per cubic foot. (This compares favourably with the present cost of production of gas from coal, $\$ 2.47$ per cubic foot).

Plant biomass is already being converted to fuel in experiments being carried out in Ghana, Ivory Coast, Indonesia, the Philippines, Brazil and elsewhere in the tropics. The high rates of photosynthesis in these areas suggest that appreciable amounts of energy could be obtained by this means for both domestic needs and for export. The low cost of labour in developing countries makes so-called energy farms even more attractive for them than for developed countries. Crops for such purposes could include sugarcane and cassava, and trees could be farmed or grown in man-made forests.

\section{Wood into plastic}

Already-known processes, together with others currently being studied, could be used to transform wood not only into energy but to organic solvents, plastics and synthetic fibres. Lignins are produced in large quantities in waste liquors from pulping processes (20 to 30 million metric tons per year throughout the world), and although they have not been successfully used for other than energy generation, some have proposed fragmenting them into low molecular weight compounds such as vanillin, or into phenols, catechols and benzene derivatives. Others suggest using them as dispersants, emulsion stabilisers or precipitants.

Wood is already used in a small way for production of tar, turpentine, acetic acid, furfural, sugar and other materials. But compared with wood's potential, such production is miniscule. Until recently, it has been cheaper to produce organic chemicals, plastics, synthetic rubber and non-cellulose fibres from oil or natural gas - but with the rising prices of these resources that may soon no longer be the case. It has been estimated that $95 \%$ of such materials could be produced from wood.

Both the semi-arid regions of the world and the humid tropics provide possibilities for utilisation of plants and trees. Desert plants often contain a relatively high proportion of hydrocarbons and other energy-rich compounds. They are the source of materials such as fibres, waxes and oils. The guayule plant in Mexico is being grown as a source of rubber. Other plants such as jojoba, mesquite and yucca are being investigated as sources of raw materials. Plant gene- tics and improved cultivation practices could turn such plants into agricultural crops, greatly increasing their yield.

The humid tropics contain a wide diversity of large trees and plants with great numbers of potentially useful compounds, such as rubber, essential oils and resins. In the temperate zone, silviculture and the conversion of agricultural land masses into biomass factories could yield both energy and chemicals.

The heavier oils will also have to be used as chemical feedstocks in the future: for example, Canada's "tar sands", now the subject of a multimillion dollar project in Alberta. The commercial development of the Canadian oil sands began 50 years ago, and at least 13 pilot or semi-commercial units have been built in an attempt to develop a satisfactory process for extraction of bitumen from surfacemined oil sands. Two commercial plants now are in operation using the hot water extraction process. Great Canadian Oil Sands Ltd., has been in operation since 1969 and has produced between 5,000 and 7,000 tonnes per day of synthetic crude oil for most of that period. Syncrude Canada Limited is in the the process of starting up a 17,000 tonnes-per-day project. Besides the $\$ 100$ million spent by the end of 1976 on experiments to extract bitumen from the deep tar sands, an additional $\$ 200$ to $\$ 300$ million is expected to be spent for this purpose during the next decade.

\section{Planning must start now}

Many of the technologies that will have to be developed to make use of the new resources will take 20 years to mature. Since the focus of the Toronto conference is the period beyond the year 2000 , this is none too soon to begin planning.

But in addition to technological development, there will be many other problems to face: resource management (particularly when the new uses compete with old ones), environmental impact, and legal and social implications.

Dr Schneider recognised this in the Canadian context: "There's no question that cellulose is going to be an important substance as a primary material and a renewable resource that could be used for energy, chemicals and materials such as plastics, or for conversion to protein or carbohydrates for food. "But we'll have to develop new, fast-growing varieties of trees if we are to use forests for cellulose. And wood supply will be a problem in Cana$\mathrm{da}$, for example, if we use it all in pulp and paper production. We have not yet begun to manage our forests." 